\title{
Beyond the Limitations of Binary Thinking: Mindfulness and the Tetralemma
}

\author{
Bhikkhu Anālayo ${ }^{1}$
}

Accepted: 31 May 2021 / Published online: 14 September 2021

(c) The Author(s) 2021

\begin{abstract}
Various dimensions of the cultivation of mindfulness in its early Buddhist historical setting can be better appreciated in the light of their doctrinal background. One aspect of this doctrinal background is the ancient Indian tetralemma, which differs from the Aristotelian logic that has informed much of Western thought. The tetralemma proposes that, in addition to affirmation and denial, at times a particular situation may be more appropriately captured by a combination of both (partly yes and partly no). Or else, another situation may call for neither affirmation nor negation. Although at first sight the resultant fourfold perspective can appear puzzling, closer inspection shows this model of thought to have a considerable potential for countering mental rigidity and enabling the transcendence of binary thought patterns, thereby being perhaps relevant to research on the relationship between mindfulness and cognitive flexibility.
\end{abstract}

Keywords Binary thinking $\cdot$ catuṣkoți $\cdot$ Cognitive flexibility $\cdot$ Dualism $\cdot$ Logic $\cdot$ Mental rigidity $\cdot$ Tetralemma

Findings in current research on the impact of mindfulness on cognitive flexibility are mixed (Lee \& Orsillo 2014, p. 209; see also Bashmakova and Shcherbakova 2021), showing that more research is needed in this area. For the time being, however, several of the relevant studies dedicated to researching this relationship offer interesting reflections on the nature of mindfulness. A survey of these provides a convenient starting point for exploring relevant perspectives in early Buddhist thought.

Zou et al. (2020, p. 2) pointed out that, on being "confronted with difficult life situations, individuals with a rigid thinking style tend to perceive the situation as unchangeable and uncontrollable." In contrast, as noted by Sinnott et al. (2020, p. 1), "cognition and the logic of problem solving interface with our patterns of viewing the world and our experiences. Those who can approach experience with an open mind, engaging in it in multiple [and] complex ways, intentionally, can experience flow, cognitive flexibility, and mindfulness." According to Shapero et al. (2018, p. 1465), it appears that "mindfulness training can change habitual patterns of responding to events by increasing the

\section{Bhikkhu Anālayo}

1 Barre Center for Buddhist Studies, 149 Lockwood Road, Barre, MA 01005, USA flexibility through which patients ... choose different coping strategies."

Moore and Malinowski (2009, p. 177) reasoned that, since "mindfulness meditation is dependent on the (re-)investment of attention on a moment by moment basis, mindfulness training should hypothetically lead to ... an increased ability to respond in a non-habitual fashion." Heidari et al. (2020, p. 138) commented that "mindfulness exercises allow a person to distance him/herself from automatic mental processing and gradually increase his/her inner views and insights and ... look for new ... solutions." Greenberg et al. $(2012$, p. 6) noted that "mindfulness practice reduces cognitive rigidity via the tendency to overlook simple novel solutions to a situation due to rigid and repetitive thought patterns formed through experience." Fabio and Towey (2018, p. 83) suggested that "long-term practice could have an effect on the way people rely on different thinking styles," as seasoned meditators can be seen to have "a preference for an holistic manner of processing information and intuitive strategies." In relation to stereotyping, according to Kang et al. (2013, p. 196),

decreasing stereotyping is possible when people are aware of their own bias. Simply being aware of one's mental states or processes - a key ingredient of mindfulness - can reduce these automatized categorizations ... mindfulness can facilitate de-automatization by fostering awareness of one's present thoughts and feelings 
... mindful individuals are more likely to understand views other than their own, recognizing that there are as many different perspectives as there are different observers ... [which] can lead to a less judgmental attitude, and thus a reduction in stereotyping.

These observations invite an exploration of the potential of mindfulness for stepping out of mental rigidity, in particular enabling a transcendence of dualistic thought patterns. It seems indeed to be the case that, by dint of its fostering of an open receptivity, the cultivation of mindfulness can encourage the assimilation of more details, therefore becoming aware of more degrees and nuances, rather than opting for a quick solution by way of binary thinking.

A doctrinal item of relevance to this topic is the ancient Indian tetralemma, whose basic departure from dualistic types of thought can be seen to inform a range of doctrinal presentations in early Buddhist thought, perhaps even the very presentation of the four establishments of mindfulness.

\section{The Ancient Indian Tetralemma}

The ancient Indian tetralemma (catușkoti) differs substantially from the dualistic logic familiar to Western thought. Its presentation is based on allowing that, in addition to affirmation and negation, both or neither of these two options could adequately reflect the situation. In other words, besides "yes" and "no," this mode of thinking recognizes that at times the situation could be more appropriately reflected by either "both yes and no" or "neither yes nor no." A simple example would be that, in addition to the distinction between the colors black and white, something could be both (namely gray) or neither (namely yellow or blue, etc.). The mode of thought encapsulated by the tetralemma in its early Buddhist usage is probably best viewed as heuristic rather than as an attempt to construct a system of formal logic (Hoffman 1982).

In order to do justice to the early Buddhist perspective, it needs to be noted that reliance on the tetralemma does not conflict with the recognition that for a range of situations the so-called "principle of the excluded middle" does apply (sometimes referred to with the Latin phrase tertium non datur, "no third [possibility] is given"), in the sense that some claims are indeed either true or false. Several doctrinal positions in early Buddhism are based on this principle. An example that explicitly involves affirming one of the four alternatives, recognized by the tetralemma, and rejecting the other three concerns the Buddha's penetrative understanding of experience. The relevant passage reports him making the following assertion:

Monastics, what in the world with its celestials ... is seen, heard, sensed, cognized, attained, sought after, and examined by the mind, that I know ... Monastics, if I were to say: 'What in the world with its celestials ... is seen, heard, sensed, cognized, attained, sought after, and examined by the mind, that I do not know, that would be a falsehood on my part ... if I were to say: 'that I both know and do not know,' that would be just the same [falsehood] ... if I were to say: 'that I neither know nor do not know,' that would be a fault on my part.

(AN 4.24: yam, bhikkhave, sadevakassa lokassa ... dițtham sutam mutam viñ̃āatam pattam pariyesitam anuvicaritam manasā, tam aham jānāmi ... yam, bhikkhave, sadevakassa lokassa ... dițtham sutam mutam viñ̃āatam pattam pariyesitam anuvicaritam manasā, tam aham na jānāmī ti vadeyyạ̣, tạn mama assa musā ... tam aham jānāmi ca na ca jānāmī ti vadeyyam, tạn p'assa tādisam eva ... tam ahạn n' eva jānāmi na na jānāmì ti vadeyyaṇ, tam mama assa kali).

The Buddha's claim to have a penetrative understanding of the range of experiences in the world leaves no scope for adopting any of the other three alternatives of the tetralemma. Another example is the contrast between ethically reprehensible and commendable deeds, which confirms that in some situations a clear-cut type of distinction is indeed warranted. A Pāli discourse reports the Buddha addressing his attendant Ānanda and making unequivocal statements in regard to ethical conduct:

Ānanda, I have unequivocally declared that immoral bodily conduct, immoral verbal conduct, and immoral mental conduct is not be undertaken ... Ānanda, I have unequivocally declared that moral bodily conduct, moral verbal conduct, and moral mental conduct is to be undertaken.

(AN 2.2.8: ekamsenāham, ānanda, akaraṇīyam vadāmi kāyaduccaritam vacīduccaritam manoduccaritan ti ... ekamsenāham, ānanda, karañỹam vadāmi kāyasucaritam vacīsucaritam manosucaritan ti).

Nevertheless, the basic distinction between what is considered to be true and false, which usually forms the foundation for unequivocal statements, can in some situations be limiting and not fully capture the whole situation. This is why, at times, thinking in terms of the tetralemma can offer a preferable approach. Jayatilleke (1963/1980, p. 342) reasoned that "this four-fold schema gave a better and finer classification of the empirical data (thus preventing much ambiguity in utterances) than that offered by the strictly dichotomous division." The potential problem that could result from relying solely on binary type of thought can be illustrated based on a description of Aristotelian dialectic by Di Lascio (2013, p. 283):

dialectical arguments mainly occur in discussions between two interlocutors, a questioner and an 
answerer ... The questioner asks, of some proposition $p$, 'Is it the case that $p$ (or not)?' By replying 'Yes'-or-'No', the answerer choses the thesis which he will defend ... Depending on whether the answerer replies 'Yes'-or-'No', the questioner tries to 'destroy' or 'construct' the thesis, that is, to deduce a negative or affirmative conclusion.

To approach the situation of opposite opinions from a dualistic framework can easily result in a perceived need of having to "destroy" what disagrees with one's own view. The influence of such binary thinking can create a pressing sense of having to demolish the position taken by the other, simply because that appears to be the only way of defending the veracity of one's own position.

If the same situation of opposite opinions were instead to be approached from the more open viewpoint of the tetralemma, the attitude toward it could change substantially. This is because, on adopting this viewpoint, it becomes clear that there is more to it than just the thought: "If the other were to be right, I would be wrong," and therefore the reasoning: "The other must be wrong, since I am obviously right." It is also possible that both opinions are correct at least to some extent, perhaps mainly differing in wording or perspective. Moreover, both opinions could equally be wrong, hence demolishing the other does not necessarily ensure that one's own position is thereby automatically proven right. Understood in this way, the mode of thought encapsulated in the tetralemma can be seen to offer a significant avenue for emerging from the limitations of binary thought. Kabat-Zinn (2018, p. 30) reasoned:

We are all wont at times to fall mindlessly into blackand-white thinking, going for the absolutes. It makes us feel better, more secure, but it is also hugely blinding ... when we fall into such thinking, if we examine it in the light of a larger awareness, we find it tends to be rigid, confining ... our black-and-white, either/or seeing and thinking leads rapidly to fixed and limiting judgments, often arrived at reflexively, automatically, without reflection, often thwarting our ability to steer our way 'home' through the vagaries of life.

\section{The Unanswered Questions}

The tetralemma as such features regularly in a set of questions about the postmortem destiny of a fully realized being, referred to as a Tathāgata, a term which in its early Buddhist usage can be understood to convey that someone is "thus gone" (Anālayo 2017). Among various spiritual practitioners in the ancient Indian setting, the four alternative positions that could be taken in this respect appear to have been employed as a way of assessing the teachings followed or propounded by someone else. The standard mode of carrying out such an investigation involved posing the following set of questions:

Does a Tathāgata exist after death? ... Does a Tathāgata not exist after death? ... Does a Tathāgata both exist and not exist after death? ... Does a Tathāgata neither exist nor not exist after death? (SN 44.7: hoti tathāgato param maraña ti? ...na hoti tathāgato param maranā ti? ... hoti ca na ca hoti tathāgato param maranā ti? ... n' eva hoti na na hoti tathāgato param maraṇā ti?).

Does a Tathāgata exist after death, not exist after death, exist and not exist after death, neither exist nor not exist after death?

(SĀ 958: 云何如來有後死, 無後死, 有無後死, 非 有非無後死?).

Passing away here, is [a Tathāgata] reborn there? ... Passing away here, is [a Tathāgata] not reborn there? Passing away here, is [a Tathāgata] both reborn there and not reborn there? Is [a Tathāgata] neither reborn there nor not reborn there?

$\left(\mathrm{SA} \bar{A}^{2}\right.$ 191: 死此生彼 ... 死此不生彼, 死此亦生彼亦 不生彼, 非生彼非不生彼).

The Buddha is on record for regularly refusing to affirm any of these four positions, much to the bewilderment of his contemporaries, and resulting in a considerable range of scholarly comments and investigations (Beckh 1919, pp. 118-121; Collins 1982, pp. 131-138; de La Vallée Poussin 1928; Edgerton 1959, pp. 82-83; Frauwallner 1956/2003, pp. 141-142; Harvey 1995, pp. 84-87; Holder 1996, p. 450; Jayatilleke 1963/1980, pp. 470-476; Kalupahana 1975, pp. 177-78; Karunadasa 2007 and 2013, pp. 129-49; Keith 1923/1979, pp. 62-67; King 1983, p. 263; Lamotte 1976, pp. 2003-2005; Manda 2005; Murti 1955/2008, pp. 36-50; Nagao 1955/1992, p. 38; Oetke 1994; Oldenberg 1881/1961, pp. 256-263; Organ 1954; Pannikar 1989/1990, pp. 61-76; Rigopoulos 1992/1993; Robinson 1972; Schrader 1904/1905; Seyfort Ruegg 1977, pp. 1-2; Smart 1964/1976, pp. 34-35; Tatia 1960; Thomas 1927/2003, pp. 201-202; Tilakaratne 1993, pp. 109-121; Vélez de Cea 2004; Warder 1970/1991, p. 120).

Inspection of relevant textual passages suggests that the apparent reason for rejecting the entire set of four alternatives relies on the assessment that, from an early Buddhist perspective, the whole set was based on a false presupposition (Anālayo 2018, p. 41). It involved the assumption that the term Tathāgata represents an entity, whereas according to early Buddhist analysis the whole of subjective experience is just a process, bereft of any substantial entity. The insight gained from such analysis 
makes it impossible to affirm or negate any of the four alternatives.

Since liberation in early Buddhism requires precisely insight into the non-existence of a self, interest in this set of questions, based on the mistaken premise of a self, is at least irrelevant if not contrary to progress toward liberation. Such concerns would be similar to a person who has been shot by a poisonous arrow and refuses to let it be extracted until being informed of a range of irrelevant details concerning the archer, the bow used for the shooting, etc. (MN 63, MĀ 221, and T 94). Just as the poisoned arrow needs to be pulled out right away to prevent the poison from spreading through the body, in the same way the tendency to reification, in particular by way of construing a self, requires being reined in (by not wasting time on these questions) and to be directly addressed through cultivating insight.

The above translated series of questions occur in an encounter between a wanderer and one of the chief monastic disciples of the Buddha. In the Pāli version, the latter explains the Buddha's refusal to take up any of the four alternatives by indicating that their pronouncers base themselves on identifying one of the senses (eye, ear, nose, tongue, body, and mind) as a self. The Chinese parallels express the same in terms of a lack of proper understanding in relation to the five aggregates (body, feeling tone, perception, formations, and consciousness). In other words, one who does not regard any of the senses or aggregates as a self becomes unable to take up any of the four positions, as these take the notion of a self as their starting point.

Understood in this manner, the issue at stake is not a rejection of the tetralemma mode of thought as such. Instead, the point made in this way is the inapplicability of all of the four options envisaged in the tetralemma, if the premises are wrong. The Buddha's refusal to affirm any of these four positions thereby corresponds to the procedure of setting a question aside, which is the last out of four modes of replying to a question. A survey of these four modes, extant in a Pāli discourse and its Tibetan parallel, takes the following form:

Monastics, there are these four responses to a question. What are the four? Monastics, there is a question to be responded to unequivocally; monastics, there is a question to be responded to analytically; monastics, there is a question to be responded to with a counter-question; and, monastics, there is a question to be set aside.

(AN 4.42: cattār' imāni, bhikkhave, pañhavyākaran̄āni. katamāni cattāri? atthi, bhikkhave, pañho ekaṃsavyākaraṇìyo; atthi, bhikkhave, pañho vibhajjavyākaranīyo; atthi, bhikkhave, pañho pațipucchāvyākarañiyo; atthi, bhikkhave, pañho thapaniyo; following the Asian editions for the sequence of listing these four).
There are four responses to a question. What are the four? A question to be responded to unequivocally; a question to be responded to analytically; a question to be responded to with a question; and one to be responded to by setting it aside.

(Up 5014: dris pa lung bstan pa ni rnam pa bzhi ste. bzhi gang zhe na? mgo gcig tu dris pa lung bstan pa dang, rnam par phye ste dris pa lung bstan pa dang, dri ba dris te lung bstan pa dang, rnam par gzhag pa lung bstan pa'o).

If the premise is wrong, un unequivocal reply is not possible. Often it may be best to set such a question aside. Alternatively, a counter-question could be employed in order to clarify that the premise is wrong, at least if it seems possible to motivate the other to question the premise. The adoption of this alternative approach can be seen in a Pāli discourse that reports a Buddhist monastic taking the (wrong) position that the tetralemma is not exhaustive. Confronted with non-Buddhist practitioners who, utilizing the four positions, had inquired about the condition of a Tathāgata after death, according to the Pāli account this monastic came out with the following statement:

Friends, on designating a Tathāgata, the supreme person, the highest person, who has attained the highest attainment, the Tathāgata designates such a one apart from these four possibilities: 'a Tathāgata exist after death,' or: 'a Tathāgata does not exist after death,' or: 'a Tathāgata both exists and does not exist after death,' or: 'a Tathāgata neither exists nor does not exist after death.' (SN 22.86: yo so āvuso tathāgato uttamapuriso paramapuriso paramapattipatto, tam tathāgato añnatra imehi catūhi thāanehi pañ̃āayamāno paññāpeti: hoti tathāgato param maraña $t i v \bar{a}$, na hoti tathāgato param maraṇa ti vā, hoti ca na ca hoti tathāgato param maraña $t i$ vā, n' eva hoti na na hoti tathāgato param maraña $t i v \bar{a} t i$; although the Chinese parallel SĀ 106 differs, Sanskrit fragments, de La Vallée Poussin 1913, p. 579, support the above presentation).

This reply earned the speaker the deserved ridicule of the non-Buddhist practitioners, as the four alternatives of the tetralemma are exhaustive and it is not possible to posit a fifth alternative. Reporting his unsuccessful encounter to the Buddha, the latter engaged this monastic in a questionand-answer exchange on the nature of a Tathāgata while still alive. The exchange made it clear to the monastic that the impermanent aggregates that make up the process of subjective experience, whether taken singly or in conjunction, do not provide a basis for the type of reification of a Tathāgata that underlies the tetralemma on a Tathāgata after death. In this way, the questions asked by the Buddha helped to clarify 
that the four proposals on the postmortem condition of a Tathāgata were based on a wrong premise.

The present case implicitly confirms the Buddhist acceptation of the notion, common in the ancient Indian setting, that the tetralemma exhaustively covers all possible options. This is where the monastic had been wrong when replying to the non-Buddhist practitioners. The solution is not some fifth alternative to the four options envisaged by the tetralemma. Instead, the solution lies in the recognition that the premise was wrong.

\section{Tetralemma Underlying Early Buddhist Teachings}

The fourfold distinction underlying the tetralemma features as a basic mode of analysis in several early Buddhist teachings. A presentation that relates the four options, envisaged by the tetralemma, to four types of action, karma, is extant in a Pāli discourse and its Sanskrit parallel:

Four [types of] action: Friends, there is dark action with dark result; friends, there is bright action with bright result; friends, there is dark-and-bright action with dark-and-bright result; friends, there is neitherdark-nor-bright action with neither-dark-nor-bright result, which leads to the ending of action.

(DN 33: cattāri kammāni: atth' āvuso kammam kaṇham kaṇhavipākaṃ; atth' āvuso kammam sukkam sukkavipākam; atth' àvuso kammam kaṇhasukkam kaṇhasukkavipākam! atth' àvuso kammam akaṇham asukkam akaṇha-asukkavipākam kammakkhayāya samvattati).

Four [types of] action: there is dark action with dark result; there is bright action with bright result; there is dark-and-bright action with dark-and-bright result; there is neither-dark-nor-bright action with neither-dark-nor-bright result, which leads to the ending of action.

(Stache-Rosen 1968, p. 113: (catvāri karmāni: asti karma krṣnam kṛṣna vi)pākam; asti karma śuklam ś(uklavipākam); asti karma krṣn(aśuklam krṣnaśuklavipākam; asti karmākrṣnam aśuklam akṛnnāśsuklavipākam karmakṣayāya samvartate); here and in the case of the next example below, the two Chinese parallels, DĀ 9 and T 12, do not cover this topic).

An exposition of these four types of action in another Pāli discourse (AN 4.232) clarifies that dark action stands for the type of conduct that leads to rebirth in hell, which is entirely painful, whereas bright action stands for what leads to rebirth in heaven, which is entirely pleasant. An action that combines both leads to rebirth in a realm where one experiences both pleasure and pain, such as in the human realm. The fourth type relates to the path to awakening, whose fruit is the transcendence of action and rebirth, be it dark/painful or bright/pleasant or both.

Another form of presentation, similarly in line with the tetralemma, involves four types of person:

Four [types of] person. Here, friends, a certain person torments themselves, pursuing the practice of tormenting themselves. Here, friends, a certain person torments others, pursuing the practice of tormenting others. Here, friends, a certain person torments themselves, pursuing the practice of tormenting themselves, and torments others, pursuing the practice of tormenting others. Here, friends, a certain person does not torment themselves, not pursuing the practice of tormenting themselves, and does not torment others, not pursuing the practice of tormenting others. Not tormenting themselves and not tormenting others, [this person] is here and now stilled, quenched, become cool, and dwells experiencing happiness, having oneself become [as if] divine.

(DN 33: cattāro puggalā. idh' āvuso ekacco puggalo attantapo hoti attaparitāpanānuyogam anuyutto. idh' āvuso ekacco puggalo parantapo hoti paraparitāpanānuyogam anuyutto. idh' àvuso ekacco puggalo attantapo ca hoti attaparitāpanānuyogam anuyutto, parantapo ca paraparitāpanānuyogam anuyutto. idh' àvuso ekacco puggalo n' eva attantapo hoti na attaparitāpanānuyogam anuyutto na parantapo na paraparitāpanānuyogam anuyutto. so anattantapo aparantapo dițthe va dhamme nicchāto nibbuto sìtibhüto sukhapațisamvvedī brahmabhūtena attanā viharati.

Four [types of] person. There is a person who torments themselves, pursuing the practice of tormenting themselves. There is a person who torments others, pursuing the practice of tormenting others. There is a person who does not torment others, not pursuing the practice of tormenting others, and who does not torment themselves, not pursuing the practice of tormenting themselves. There is a person who torments themselves, pursuing the practice of tormenting themselves, and who torments others, pursuing the practice of tormenting others. (Stache-Rosen 1968, p. 122: catvā(rah)p(u)dagalah. asti pudga(la ātmanta)pa ātmaparitāpan(āyogam anuyuktaḥ; asti pudgalah paramtapah parapari) tāpanāyogam anuyuktah; asti pudgalo na paramtapo na parapa(r)itā(panāyogam a)nuyukto nātmantapo (nātmaparitāpanāyo)gam anuyukt(ah); (a)sti pudgala ātma(n)tapa ātmapari(tāpanāyoga)m anuyuktah paramt(apah paraparitāpanāyoga)m anuyuk(tah); 
which is followed by taking up again the third case, after which there is a lacuna).

The implications of these four can be appreciated with the help of another Pāli discourse (MN 51), which follows the same listing with detailed explanations for each case: The category of tormenting oneself stands for ascetic self-mortification, whereas tormenting others stands for those who make a living by killing sentient beings. The category that combines both finds illustration in a king who has a sacrifice performed on his behalf and at the same time undertakes some forms of self-mortification. The fourth category in turn stands for someone who has reached awakening.

\section{The Four Establishments of Mindfulness}

The traditional cultivation of mindfulness involves four spheres of contemplation in the form of the four establishments of mindfulness (satipatțāna, smrtyupasthāna, 念處, dran pa nye bar gzhag pa). These are contemplation of the body, feeling tones, the mind, and dharmas. The sequence of these four appears to reflect an increasing subtlety of meditation practice.

Besides covering body on the one hand and mind on the other, one such establishment of mindfulness concerns feeling tones (vedana, 受, tshor $b a$ ). Although feeling tones are of course part of the mind, as a body bereft of mind will no longer experience feeling tones, at the same time feeling tones have a pronounced somatic dimension (Anālayo 2013, p. 121). When viewed from the fourfold mode of thought under discussion, feeling tone could be considered to fit the case of being "both body and mind," reflecting the third mode recognized in the tetralemma (the first being equivalent to the body and the second to the mind as being "not the body").

If this much is granted, it remains to be seen if the last establishment of mindfulness can in some way be understood to correspond to the fourth possibility envisaged by the tetralemma. Establishing such a correspondence is not without its difficulties, because the precise significance of "dharmas" in this context is not straightforward. A common rendering of contemplation of dharmas as "contemplation of mental objects" fails to solve the conundrum (Anālayo 2003, p. 182). Anything contemplated with mindfulness must become an object of the mind, wherefore the idea of mental objects is not sufficiently specific to characterize the fourth establishment of mindfulness.

A comparison of the Satipatthanna-sutta and its two Chinese Ágama parallels shows agreement on one exercise regarding the rubric of contemplation of dharmas (Anālayo 2013, p. 174), which is contemplation of the awakening factors (bojjhangga, bodhyainga, 覺支, byang chub kyi yan lag).
The actual instructions for such contemplation of the awakening factors in the Satipatthāna-sutta and its Madhyamaagama parallel begin with a recognition of the presence or absence of an awakening factor, followed by offering the following instruction (here given for the case of the first awakening factor of mindfulness):

One knows how the unarisen mindfulness awakening factor arises, and one knows how the arisen mindfulness awakening factor is perfected by development. (MN 10: yathā ca anuppannassa satisambojjhañgassa uppādo hoti tañ ca pajānāti, yathā ca uppannassa satisambojjhañgassa bhāvanāya pāripūrī hoti tañ ca pajānāti).

One knows, as it really is, how the unarisen mindfulness awakening factor arises; and one knows, as it really is, how the arisen mindfulness awakening factor is then maintained without loss or deterioration, and is further developed and increased.

(MĀ 98: 若未生念覺支而生者, 知如真; 若已生念 覺支便住不忘而不衰, 退轉修增廣者, 知如真).

The instructions, which apply similarly to the other six awakening factors (investigation of states, energy, joy, tranquility, concentration, and equipoise), involve a practical application of conditionality. The task of mindful contemplation in relation to the awakening factors is to furnish the crucial information about the causes responsible for their arising and their disappearing, thereby enabling the meditator to take the required steps in order to foster the former and prevent the latter.

The corresponding instruction on the awakening factors in the Ekottarika-ägama version, here again illustrated with the case of the first awakening factor of mindfulness, differs. It proceeds as follows:

One cultivates the mindfulness awakening factor supported by insight, supported by dispassion, and supported by cessation, discarding bad states.

(EĀ 12.1: 修念覺意, 依觀，依無欲，依滅盡，捨諸 惡法).

In this instruction, the task is to relate the cultivation of the awakening factor of mindfulness (and the others) to insight themes that provide the conditions for the actual breakthrough to awakening to take place. In spite of taking different forms, a theme common to the instructions in the three parallels appears to be a practical application of conditionality.

The same is also evident in the instructions for contemplation of dharmas found in at least two of the three discourse versions, which are contemplation of the hindrances and of the sense spheres. In the case of the former, the task of mindfulness is to know how a hindrance arises and how it 
is removed, a knowledge that requires insight into the causes for arising and removal. The contemplation of the sense spheres in turn concerns the fetter that arises "in dependence" (pațicca/緣) on a sense and its object.

In this way, these contemplations of dharma involve, in one way or another, a mindful exploration of the principle of dependent arising. The idea here is not just an investigation of this principle as such, but much rather putting it to good use under the overarching aim of progressing to awakening. For this purpose, the conditions for the arising and the removal of the hindrances and fetters are of considerable significance, as are the conditions for the cultivation of the awakening factors and for how these should be combined with insight themes in order to lead to the breakthrough to liberation.

Dependent arising as such is of course a key doctrine in early Buddhism. According to a well-known dictum, seeing dependent arising, in the sense of having a direct experiential vision, equals seeing the Buddha's teaching:

One who sees dependent arising, sees the Dharma; one who sees the Dharma, sees dependent arising. (MN 28: yo paticcasamuppādam passati so dhammam passati; yo dhammam passati so pațiccasamuppādam passatī ti).

If one sees dependent arising, one then sees the Dharma; if one sees the Dharma, one then sees dependent arising.

(MĀ 30: 若見緣起便見法, 若見法便見緣起).

From this perspective, then, the instructions on contemplation of dharmas found in the Satipațthāna-sutta and at least one (or even both) of its Chinese Ägama parallels can be seen to converge on the crucial principle of dependent arising (=the Dharma), applied to states (dharmas) such as the hindrances, the sense spheres, and the awakening factors. On this understanding, the fourth establishment of mindfulness would indeed differ significantly from the preceding three, which do not come with such a clear-cut implementation of dependent arising. This is not to suggest that insight into dependent arising could not arise with any of the other contemplations found in the parallel versions' descriptions of the first, second, and third establishment of mindfulness. The point is only that, with the fourth establishment of mindfulness, contemplation comes to be intentionally and explicitly directed in this way.

If this much is granted, it would be possible to consider contemplation of dharmas to exemplify the fourth case of the tetralemma. A mindful exploration of dependent arising is concerned with a doctrinal principle which, although it of course applies to body, feeling tones, and mental states, as such cannot be equated with just the body or just the mind, nor with a combination of the two comparable to the case of feeling tones.
An identification of the basic fourfold division of mindfulness practice with the mode of thought underlying the tetralemma does not appear to be attested in the traditional sources and for this reason remains just a tentative suggestion. Nevertheless, granting the above envisaged possibility would enable visualizing the scheme of the four establishments of mindfulness as reflecting the fourfold alternatives encapsulated in the tetralemma. On this assumption, then, not only does the quality of mindfulness in itself encourage a broadening of perspective beyond the narrow confines of dualistic contrasts, but its formal cultivation by way of the four establishments of mindfulness can be interpreted as an actualization of the tetralemma mode of thinking, and thereby as an additional invitation to step out of the limitations of binary thinking.

Acknowledgements The author acknowledges his indebtedness to Chris Burke for commenting on a draft version of this article.

Funding Open Access funding enabled and organized by Projekt DEAL.

\section{Declarations}

Ethical Approval This article does not contain any studies performed by the author with human participants or animals.

Conflict of Interest The author declares that there is no conflict of interest.

Abbreviations AN: Añguttara-nikāya; DĀ: Dīrgha-āgama (T 1); DN: Dīgha-nikāya; EĀ: Ekottarika-āgama (T 125); MĀ: Madhyamaāgama (T 26); MN: Majjhima-nikāya; SĀ: Samyukta-āgama (T 99); SĀ2 : Samyukta-āgama (T 100); SN: Samyutta-nikāya; T: Taishō edition;

Up: Abhidharmakośopāyikā-țīkā

Open Access This article is licensed under a Creative Commons Attribution 4.0 International License, which permits use, sharing, adaptation, distribution and reproduction in any medium or format, as long as you give appropriate credit to the original author(s) and the source, provide a link to the Creative Commons licence, and indicate if changes were made. The images or other third party material in this article are included in the article's Creative Commons licence, unless indicated otherwise in a credit line to the material. If material is not included in the article's Creative Commons licence and your intended use is not permitted by statutory regulation or exceeds the permitted use, you will need to obtain permission directly from the copyright holder. To view a copy of this licence, visit http://creat ivecommons.org/licenses/by/4.0/.

\section{References}

Anālayo, Bh. (2003). Satipatthāna, the direct path to realization. Cambridge: Windhorse Publications.

Anālayo, Bh. (2013). Perspectives on satipatțhāna. Cambridge: Windhorse Publications.

Anālayo, Bh. (2017). Some renditions of the term Tathāgata in the Chinese Āgamas. Annual Report of the International Research Institute for Advanced Buddhology at Soka University, 20, 11-21. 
Anālayo, Bh. (2018). Rebirth in early Buddhism and current research. Boston: Wisdom Publications.

Bashmakova, I., \& Shcherbakova, O. (2021). Just open your mind? A randomized, controlled study on the effects of meditation on creativity. Frontiers in Psychology, 12(663881), 1-14. https:// doi.org/10.3389/fpsyg.2021.663881.

Beckh, H. (1919). Buddhismus (Der Buddha und seine Lehre), I Einleitung, Der Buddha. Berlin: Göschen.

Collins, S. (1982). Selfless persons, imagery and thought in Theravāda Buddhism. Cambridge: Cambridge University Press.

de La Vallée Poussin, L. (1913). Documents sanscrits de la seconde collection M. A. Stein. Journal of the Royal Asiatic Society, 569-580.

de La Vallée Poussin, L. (1928). Agnosticism (Buddhist). In J. Hastings (Ed.), Encyclopedia of Religion and Ethics, Volume 1, (pp. 220-225). New York: Charles Scribner's Sons.

Di Lascio, E. V. (2013). Aristotle: Logic. In F. Sheffield \& J. Warren (Eds.), Routledge Companion to Ancient Philosophy (pp. 272289). London: Routledge.

Edgerton, F. (1959). Did the Buddha have a system of metaphysics? Journal of the American Oriental Society, 79, 81-85.

Fabio, R. A., \& Towey, G. E. (2018). Long-term meditation: The relationship between cognitive processes, thinking styles and mindfulness. Cognitive Processing, 19(1), 73-85. https://doi.org/10.1007/ s10339-017-0844-3

Frauwallner, E. (1956/2003). Geschichte der indischen Philosophie, I. Band, die Philosophie des Veda and des Epos, der Buddha und der Jina, das Sāmkhya und das klassische Yoga-System. Aachen: Shaker Verlag.

Greenberg, J., Reiner, K., \& Meiran, N. (2012). 'Mind the trap': Mindfulness practice reduces cognitive rigidity. PloS one, 7(5), 1-8. https://doi.org/10.1371/journal.pone.0036206

Harvey, P. (1995). The selfless mind; personality, consciousness and Nirvāna in early Buddhism. Richmond Surrey: Curzon.

Heidari, S., Maktabi, G., Shehni Yailagh, M., \& Behroozi, N. (2020). The effect of mindfulness training on cognitive flexibility in sixth-grade female students. Iranian Evolutionary and Educational Psychology Journal, 2(2), 131-140. https://doi.org/10.29252/ieepj.2.2.131

Hoffman, F. J. (1982). Rationality in early Buddhist four fold logic. Journal of Indian Philosophy, 10, 309-337.

Holder, J. J. (1996). The early Buddhist theory of truth, a contextualist pragmatic interpretation. International Philosophical Quarterly, $36(4), 443-459$.

Jayatilleke, K.N. (1963/1980). Early Buddhist theory of knowledge. Delhi: Motilal Banarsidass.

Kabat-Zinn, J. (2018). Meditation is not what you think, mindfulness and why it is so important. New York: Hachette.

Kalupahana, D. J. (1975). Causality, the central philosophy of Buddhism. Honolulu: University Press of Hawai'i.

Kang, Y., Gruber, J., \& Gray, J. R. (2013). Mindfulness and de-automatization. Emotion Review, 5(2), 192-201. https://doi.org/10.1177/ 1754073912451629

Karunadasa, Y. (2007). The unanswered questions: Why were they unanswered? A re-examination of the textual data. Pacific World, Third Series, 9, 3-31.

Karunadasa, Y. (2013). Early Buddhist teachings, the middle position in theory and practice. Hong Kong: Centre of Buddhist Studies, University of Hong Kong.

Keith, A. B. (1923/1979). Buddhist philosophy in India and Ceylon. Delhi: Oriental Books Reprint Corporation.

King, W. L. (1983). The existential nature of Buddhist ultimates. Philosophy East and West, 33(3), 263-271.

Lamotte, É. (1976). Le Traité de la Grande Vertu de Sagesse de Nāgārjuna (Mahāprajñāpāramitāśāstra), tome IV. Louvain-laNeuve: Institut Orientaliste.

Lee, J. K., \& Orsillo, S. M. (2014). Investigating cognitive flexibility as a potential mechanism of mindfulness in generalized anxiety disorder.
Journal of Behavior Therapy and Experimental Psychiatry, 45(1), 208-216. https://doi.org/10.1016/j.jbtep.2013.10.008

Manda, M. (2005). The meaning of Tathāgata in the avyākata questions. In Buddhism and Jainism, Essays in Honour of Dr. Hojun Nagasaki on His Seventieth Birthday (pp. 724-713). Kyoto: Committee for the Felicitation of Dr. Hojun Nagasaki's Seventieth Birthday.

Moore, A., \& Malinowski, P. (2009). Meditation, mindfulness and cognitive flexibility. Consciousness and Cognition, 18(1), 176-186. https://doi.org/10.1016/j.concog.2008.12.008

Murti, T. R. V. (1955/2008). The central philosophy of Buddhism, a study of the Mādhyamika system. Oxon: Routledge.

Nagao G. M. (1955/1992). The silence of the Buddha and its Madhyamic interpretation. In L. S. Kawamura (ed.) Mādhyamika and Yogācāra, a study of Mahāyāna philosophies, Collected Papers of G. M. Nagao (pp. 35-49). Delhi: Sri Satguru Publications.

Oetke, C. (1994). Die unbeantworteten Fragen und das Schweigen des Buddha. Wiener Zeitschrift Für Die Kunde Südasiens, 38, 85-120.

Oldenberg, H. (1881/1961). Buddha, sein Leben, seine Lehre, seine Gemeinde. München: Wilhelm Goldmann Verlag.

Organ, T. W. (1954). The silence of the Buddha. Philosophy East and West, 4(2), 125-140.

Pannikar, R. (1989/1990). The silence of God, the answer of the Buddha. New York: Orbis Books.

Rigopoulos, A. (1992/1993). The avyākatāni and the catuskoti form in the Pāli Sutta Pitaka. East and West 42(2-4), 227-259 and 43(1-4), 115-140.

Robinson, R. H. (1972). Some methodological approaches to the unexplained points. Philosophy East and West, 22(3), 309-323.

Schrader, O. F. (1904/1905). On the problem of Nirvāna. Journal of the Pali Text Society, 157-170.

Seyfort Ruegg, D. (1977). The uses of the four points of the catuskoti and the problem of the description of reality in Mahāyanna Buddhism. Journal of Indian Philosophy, 5, 1-71.

Shapero, B. G., Greenberg, J., Mischoulon, D., Pedrelli, P., Meade, K., \& Lazar, S. W. (2018). Mindfulness-based cognitive therapy improves cognitive functioning and flexibility among individuals with elevated depressive symptoms. Mindfulness, 9, 1457-1469. https://doi.org/10.1007/s12671-018-0889-0

Sinnott, J., Hilton, S., Wood, M., \& Douglas, D. (2020). Relating flow, mindfulness, cognitive flexibility, and postformal thought: Two studies. Journal of Adult Development, 27(1), 1-11. https://doi. org/10.1007/s10804-018-9320-2

Smart, N. (1964/1976). Doctrine and argument in Indian philosophy. New Jersey: Humanities Press.

Stache-Rosen, V. (1968). Dogmatische Begriffsreihen im älteren Buddhismus II; das Sañgītisūtra und sein Kommentar Sañgītiparyāya. Berlin: Akademie Verlag.

Tatia, N. (1960). The avyākṛtas or indeterminables. Nava-NālandāMahāvihāra Research Publication, 2, 141-159.

Thomas, E. J. (1927/2003). The life of Buddha as legend and history. Delhi: Munshiram Manoharlal.

Tilakaratne, A. (1993). Nirvana and ineffability, a study of the Buddhist theory of reality and language. Sri Lanka: University of Kelaniya, Postgraduate Institute of Pali and Buddhist Studies.

Vélez de Cea, A. (2004). The silence of the Buddha and the questions about the Tathāgata after death. Indian International Journal of Buddhist Studies, 5, 119-141.

Warder, A. K. (1970/1991). Indian Buddhism. Delhi: Motilal Banarsidass.

Zou, Y., Li, P., Hofmann, S. G., \& Liu, X. (2020). The mediating role of non-reactivity to mindfulness training and cognitive flexibility: A randomized controlled trial. Frontiers in Psychology, 11(1053), 1-13. https://doi.org/10.3389/fpsyg.2020.01053

Publisher's Note Springer Nature remains neutral with regard to jurisdictional claims in published maps and institutional affiliations. 